\title{
Emissions from Trucks using Fischer-Tropsch Diesel Fuel
}

Paul Norton, Keith Vertin and Brent Bailey National Renewable Energy Lab (NREL)

Nigel N. Clark and Donald W. Lyons

West Virginia Univ. (WVU)

Stephen Goguen and James Eberhardt US Department of Energy (DOE)

Reprinted From: Alternative Fuels 1998

(SP-1391) 
The appearance of the ISSN code at the bottom of this page indicates SAE'S consent that copies of the papermaybe made forpersonal or internaluse of specificclients. Thisconsent is given on the condition however, that the copier pay a $\$ 7.00$ perarticle copyfeethrough the Copyright Clearance Center, Inc. Operations Center, 222 Rosewood Drive, Danvers, MA 01923 forcopying beyond that permitted by Sections 107 or 108 of the U.S. Copyright Law. This consent does not extend to otherkinds of copying such as copying for general distribution, for advertising orpromotional purposes, forcreating new collective works, or for resale.

SAE routinely stocks printed papers for a period of three years following date of publication. Directyour orders to SAE CustomerSales and Satisfaction Department.

Quantity reprint rates can be obtained from the CustomerSales and Satisfaction Department.

To requestpermissionto reprint a technical paperorpermission to use copyrighted SAE publications in otherworks, contact the SAE Publications Group.

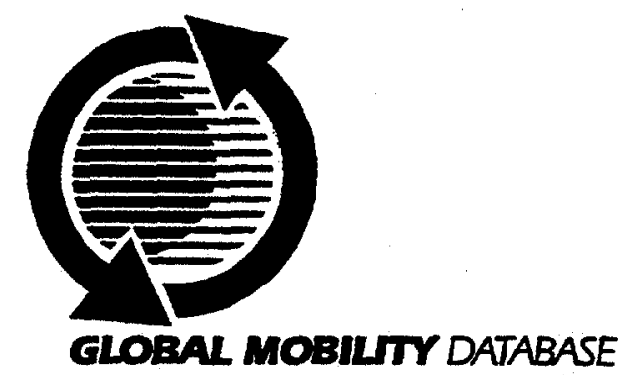

All SAE papers, standards, and selected booksareabstractedandindexedintheSAE GlobalMobility Database.

Nopart of this publication may by reproduced in anyform, inanelectronic retrievalsystem or othenwise, without the priorwritten permission of the publisher.

\section{ISSN0148-7191}

Copyright 1998 Society of Automotive Engineers, inc.

Positionsand opinionsadvanced in thispaperare those oftheauthor(s) and notnecessarity those of SAE. The author is solely responsible for the content of the paper. Aprocess is available by which discussions will be printed with the paper if it is published in SAE Transactions. For permission to publish this paper in full or in part, contact the SAE Publications Group.

Personswishing to submit papers to be considered for presentation orpublication through SAE should send the manuscript or a 300 word abstract of a proposed manuscript to: Secretary, Engineering Meetings Board, SAE. 


\title{
Emissions from Trucks using Fischer-Tropsch Diesel Fuel
}

\author{
Paul Norton, Keith Vertin and Brent Bailey \\ National Renewable Energy Lab (NREL) \\ Nigel N. Clark and Donald W. Lyons \\ West Virginia Univ. (WVU) \\ Stephen Goguen and James Eberhardt \\ US Department of Energy (DOE)
}

Copyright (C) 1998 Society of Automotive Engineers, Inc.

\section{ABSTRACT}

The Fischer-Tropsch (F-T) catalytic conversion process can be used to synthesize diesel fuels from a variety of feedstocks, including coal, natural gas and biomass. Synthetic diesel fuels can have very low sulfur and aromatic content, and excellent autoignition characteristics. Moreover, Fischer-Tropsch diesel fuels may also be economically competitive with California diesel fuel if produced in large volumes.

overview of Fischer-Tropsch diesel fuel production and engine emissions testing is presented. Previous engine laboratory tests indicate that F-T diesel is a promising alternative fuel because it can be used in unmodified diesel engines, and substantial exhaust emissions reductions can be realized.

The authors have performed preliminary tests to assess the real-world performance of F-T diesel fuels in heavyduty trucks. Seven White-GMC Class 8 trucks equipped with Caterpillar 10.3 liter engines were tested using F-T diesel fuel. Vehicle emissions tests were performed using West Virginia University's unique transportable chassis dynamometer.

- The trucks were found to perform adequately on neat F-T diesel fuel. Compared to a California diesel fuel baseline, neat F-T diesel fuel emitted about $12 \%$ lower oxides of nitrogen (NOX) and $24 \%$ lower particulate matter over a five-mile driving cycle.

\section{INTRODUCTION}

The Energy Policy Act of 1992 (EPACT) was enacted to stimulate the research, development, and accelerated introduction of alternative fuel technologies in the United tes. The objective of EPACT is to reduce the ..ation's dependence on imported petroleum by pursuing renewable and domestically produced energy resources. Under EPACT, DOE has established programs to promote energy diversity and the displacement of crude oil-based motor fuels.

"Gas-to-liquids" (GTL) process technology is one promising approach for achieving energy diversity. There has been heightened interest in GTL technology in recent years, as researchers and industrial firms are demonstrating good production economics. GTL fuel and chemical plants are emerging in developing countries. GTL pilot piants are also being developed for remote and off-shore applications to liberate remote and stranded natural gas reserves.

Fischer-Tropsch (F-T) is a GTL chemical conversion process that is being successfully used to produce high quality gasoline and diesel fuel products from coal, natural gas and biomass feedstocks. The process originates from Franz Fischer and Hans Tropsch who patented the synthesis of petroleum at normal pressure using metal catalysts in 1926 [1]. German industries further developed the process to produce FischerTropsch motor fuels during World War II. F-T diesel fuels are typically synthesized using a three-step procedure [2-6]:

- A synthesis gas containing mostly carbon monoxide and hydrogen is produced. Natural gas is reformed with pure oxygen or air, or coal is gasified in the presence of oxygen and steam.

- Through F-T catalysis, the synthesis gas is converted into liquid hydrocarbons. The lengths of the hydrocarbon chains are determined by catalyst selectivity and reaction conditions. The process can be tuned to yield lighter or heavier hydrocarbons.

- The resulting waxy synthetic crude is upgraded using standard hydrocracking and isomerization processes and fractionated into middle distillate fuels. 
In the 1950s, the South Africans further developed F-T processes to synthesize transportation fuels and chemicals from domestic coal reserves. Sasol completed a synthetic fuels plant in 1955, and further increased synthetic fuels production capacity during the oil embargo in the 1970s. Today, F-T diesel is used as a neat transportation fuel in South Africa, and also as a blend stock for use with petroleum-derived diesel to achieve low-sulfur-content specifications. Sasol has recently developed cobalt-based catalyst and slurry phase distillate reactor technology to further improve the economics for producing F-T diesel fuel [2].

Shell has developed cobalt-based catalyst technology to synthesize middle distillates from natural gas in a commercial-scale plant in Bintulu, Malaysia [3,4]. Exxon, Texaco, Chevron, Phillips, ARCO and others are also involved in developing pilot or commercial-scale plants to produce synthetic fuels and chemicals using the F-T process.

A wide array of catalyst and reactor technologies has been developed to produce F-T fuels. Consequently, synthetic diesel fuel properties can vary substantially depending on the process technology and streams being blended. But generally, F-T diesel fuels have favorable characteristics for use in compression ignition engines.

Favorable attributes include:

- Liquid phase at ambient conditions

- Miscible in conventional petroleum-derived diesel

- Good autoignition characteristics (cetane number of 50-75 typically)

- Low sulfur (typically less than 10 ppm)

- Low aromatics (less than 3 vol\% possible)

- Energy density comparable to conventional diesel

- Fuel tank flammability similar to conventional diesel

- Suitable for use in unmodified diesel engines

- Transportable as a liquid in existing petroleum infrastructure.

F-T diesel fuels may also be economically competitive with California diesel fuel if produced in large volumes. For a commercial-scale plant, synthetic fuel price estimates range from $\$ 20$ to $\$ 25$ per barrel of product $[2,5,6,7]$.

The performance and emissions of F-T diesel fueled engines have been studied in engine testing laboratories [8-11]. All of these studies have confirmed that F-T diesel fuel can be used in unmodified diesel engines, and that some emissions benefits may be realized.

Sasol's Slurry Phase Distillate (SSPD) diesel fuel has been evaluated in a Detroit Diesel Series 6012.7 liter diesel truck engine [8]. Substantial reductions of oxides of nitrogen $\left(\mathrm{NO}_{x}\right)$ and particulate matter (PM) emissions were demonstrated for SSPD and SSPD-diesel blends over the hot-start portion of the EPA Federal Test Procedure (FTP). Results for a SSPD fuel blended in conventional No. 2-D grade diesel fuel are reproduced in Figures 1 and 2. The study concluded that SSPD could be blended with conventional No. 2-D diesel fuel in 40:60 proportions to produce emissions equivalent to a California diesel fuel.

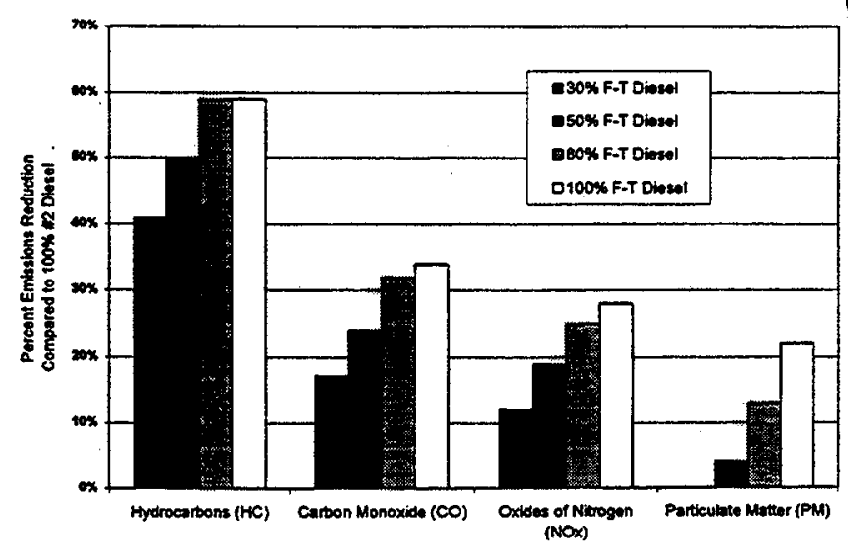

Figure 1: Percent emissions reduction using Sasol's Slurry Phase Distillate (SSPD) diesel fuel compared to using No. 2 diesel fuel in a DDC Series 60 engine [8].

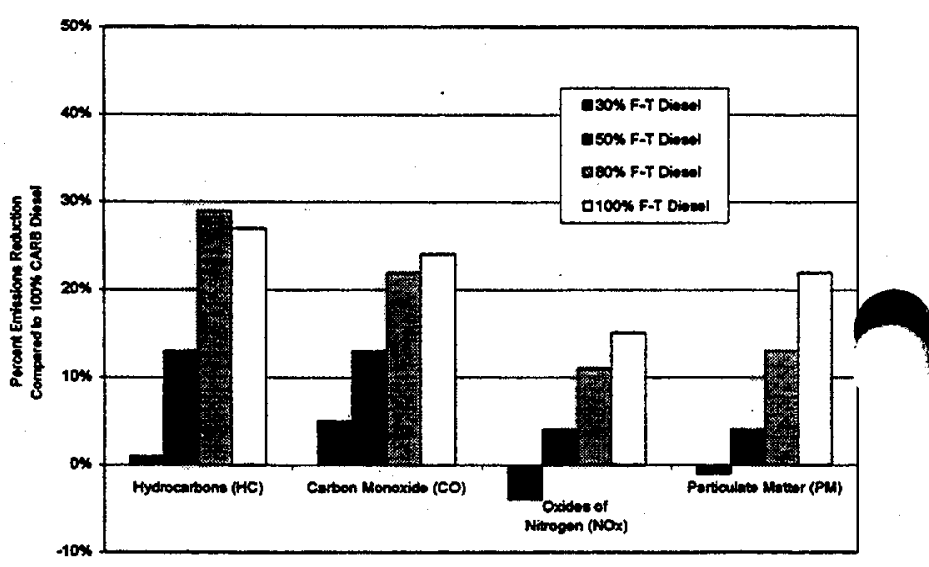

Figure 2: Percent emissions reduction using Sasol's Slurry Phase Distillate (SSPD) diesel fuel compared to using California diesel fuel in a DDC Series 60 engine [8].

Three experimental F-T diesel fuels were evaluated on an unmodified Detroit Diesel Series 6011.1 liter diesel truck engine at Southwest Research Institute [9]. When fueled with neat F-T diesel fuels, about $3 \%$ to $8 \%$ lower torque was observed over the speed range of the engine relative to diesel-fueled torque levels. This power loss was presumably due to the lower energy density of F-T diesel fuels, and could potentially be overcome with injection timing changes. Using the same injection timing settings, brake specific $\mathrm{NO}_{\mathrm{x}}$ and $\mathrm{PM}$ emissions for the neat F-T diesel fuels were on average about $8 \%$ and $30 \%$ lower, respectively, than No. 2 diesel fuel emissions for the hot-start FTP transient cycle.

Shell's middle distillate synthetic diesel fuel has recently been tested in the Daimler-Benz OM611 2.2 liter turbodiesel using a 13-mode steady-state procedure [10]. Compared to a No. 2 diesel baseline fuel, neat F-7 diesel fuel emitted about $6 \%$ lower $\mathrm{NO}_{x}$ and $37 \%$ lower PM on a equally weight-averaged basis. A joint European study also confirms that neat Fischer-Trospch 
fuel containing only paraffins produces similar reductions in emitted pollutants, for a variety of light and heavy duty vehicles and engines [11].

Due in part to the success of these engine laboratory tests, F-T diesel is being considered as a candidate fuel for the DOE/NREL Alternative Fuel Truck Evaluation Project [12]. F-T diesel shows promise for displacing crude oil-derived diesel fuels because of its fuel characteristics, favorable production economics, and the potential for reducing emitted pollutants. Some preliminary engine and vehicle tests were recently performed to prepare for a possible on-road demonstration of a F-T diesel fueled truck. The results of these scoping tests are reported in this paper.

\section{TEST FUELS}

Three test fuels were used for preliminary engine tests:

- No. 2-D grade diesel -

EPA "on-road" diesel, $0.05 \%$ sulfur max

- California No. 2 diesel

- $100 \%$ Shell F-T diesel.

Three test fuels were used for the vehicle tests:

- California No. 2 diesel

- 50:50\% F-T:California diesel blend with fuel lubricity additive

- $100 \%$ Shell F-T diesel with fuel lubricity additive.

A small batch of the F-T diesel fuel was obtained from Shell's middle distillate synthesis plant in Bintulu, Malaysia. This plant reforms natural gas with pure oxygen to produce the synthesis gas. A proprietary cobalt-based catalyst is used in a fixed bed reactor to convert the synthesis gas into liquid hydrocarbons. The waxy part of the synthesis product is selectively hydrocracked to the desired middle distillate products $[3,4]$.

The Shell F-T diesel fuel was colorless and nearly odorless. A series of ASTM D975 diesel fuel tests and fuel lubricity rig tests was performed to determine the fuel properties, and the results are summarized in Table 1 [13]. These lab tests confirmed that the synthetic fuel met engine manufacturer specifications, and thereby ensured that engine warranties would not be invalidated while performing vehicle emissions tests. The F-T diesel fuel was found to have properties conducive to low emissions, including a cetane number greater than 74, sulfur content less than $5 \mathrm{ppm}$, and aromatic content of about $0.3 w t \%$.

High frequency reciprocating rig tests (HFRR, ASTM D6079) revealed that the lubricity of neat F-T diesel fuel was unacceptable, because the wear scar exceeded the 380-micron limit specified by the engine manufacturer (Table 1). A 50:50\% F-T:California diesel blended fuel was tested and also exceeded the wear scar limit, indicating that even the use of F-T blended fuels may increase wear in fuel injection system components. To prevent undue fuel system wear, the Paradyne 655 fuel lubricity additive from the Paramins Division of Exxon was added to the neat F-T fuel at a $200 \mathrm{ppm}$ treat rate. The lubricity additive proved to be effective based on repeat testing on the HFRR. Lubricity tests were also performed on the SLBOCLE rig (Scuffing Load Ball-OnCylinder Lubricity Evaluator) to further demonstrate the effectiveness of the lubricity additive for neat and blended F-T fuels.

Different variants of California No. 2 diesel fuel were used for laboratory tests, engine tests and vehicle tests. Properties of the California diesel fuel used for vehicle tests are reported in Table 1[14].

\section{ENGINE TESTING}

Preliminary engine lab tests were performed to quickly ensure that F-T diesel fuels could be used in unmodified diesel engines without significant power loss. These tests also confirmed that emissions reductions could be measured, before committing to more costly vehicle chassis dynamometer tests.

Fuel performance and emissions were compared using a 1994 Navistar T444E V8 7.3 liter diesel engine at West Virginia University. Emissions were measured for the hot-start portion of the FTP transient emissions test cycle. Triplicate emissions tests were performed for conventional No. 2-D diesel, California No. 2 diesel, and for neat Fischer-Trospch diesel fuels.

Engine performance was adequate while using neat F-T diesel fuel. Neat F-T diesel fuel emitted about $14 \%$ lower $\mathrm{NO}_{\mathrm{x}}$ and $13 \%$ lower $\mathrm{PM}$ on average, compared to the conventional No. 2-D diesel baseline fuel as shown in Table 2. The F-T diesel fuel exhibited only slightly lower emissions than the California diesel fuel based on preliminary engine laboratory testing. 
Table 1: Test Fuel Properties

\begin{tabular}{|c|c|c|c|c|c|c|c|}
\hline Analysis & ASTM & Units & $\begin{array}{c}100 \% \text { F-T } \\
\text { Diesel [13] }\end{array}$ & $\begin{array}{c}50: 50 \% \\
\text { F-T:California } \\
\text { Diesel [13] } \\
\end{array}$ & $\begin{array}{c}100 \% \text { F-T Diesel } \\
\text { with Lubricity } \\
\text { Additive [13] }\end{array}$ & $\begin{array}{c}\text { California Diesel } \\
\text { Fuel for Vehicle } \\
\text { Tests [14] }\end{array}$ & $\begin{array}{c}\text { Fuel Requirements } \\
\text { from Engine } \\
\text { Manufacturer[15] }\end{array}$ \\
\hline Flash Point & 093 & ${ }^{\circ} \mathrm{C}$ & $\overline{72}$ & 101 & & & legal limit \\
\hline Cloud Point & D2500 & ${ }^{\circ} \mathrm{C}$ & 3 & -5 & & & $\begin{array}{l}\text { max not above lowest } \\
\text { ambient temperature }\end{array}$ \\
\hline Water \& Sediment & D1796 & $\%$ & $<0.02$ & $<0.02$ & & & $0.1 \max$ \\
\hline Carbon Residue & D524 & $w t \%$ & 0.02 & 0.05 & & & $1.05 \max$ \\
\hline Ash & $\mathrm{D} 482$ & $w t \%$ & $<0.001$ & $<0.001$ & & & $0.02 \max$ \\
\hline $\begin{array}{l}\text { Distillation } \\
\text { IBP } \\
10 \% \\
50 \% \\
90 \% \\
\text { FBP }\end{array}$ & D86 & ${ }^{\circ} \mathrm{C}$ & $\begin{array}{l}210 \\
260 \\
300 \\
331 \\
338\end{array}$ & $\begin{array}{l}191 \\
224 \\
282 \\
332 \\
348\end{array}$ & . & $\begin{array}{l}175 \\
213 \\
268 \\
332 \\
363 \\
\end{array}$ & $\begin{array}{l}282 \max \\
360 \max \end{array}$ \\
\hline Kinematic Viscosity & D445 & cSt@ $90^{\circ} \mathrm{C}$ & 3.57 & 2.91 & 3.57 & & $1.4 \min , 20.0 \max$ \\
\hline Sulfur & D129 & $w t \%$ & $<0.05$ & $<0.05$ & & & \multirow{3}{*}{$3 w t \% \max$} \\
\hline Sulfur & D5453 & ppm & $<5^{\star \star}$ & & & & \\
\hline Sulfur & D4294 & $w t \%$ & & & & 0.01 & \\
\hline Corrosion, $50^{\circ} \mathrm{C}$ for 3 hours & D130 & & $1 \mathrm{~A}$ & $1 \mathrm{~A}$ & & & no. 3 max \\
\hline Cetane Number & D613 & & $>74^{\star}$ & 69.0 & & & $40 \mathrm{~min}$ \\
\hline Cetane Index & D4737 & & & & & 53.7 & \\
\hline Density @ $15^{\circ} \mathrm{C}$ & D40.52/D1298 & Sp. Gravity & 0.7845 & 0.8089 & & 0.8337 & \\
\hline API Gravity@15.6 $\mathrm{C}$ & D287 & ${ }^{\circ} \mathrm{API}$ & 54 & 47.9 & & & $30 \min , 45 \max$ \\
\hline Pour Point & D97 & ${ }^{\circ} \mathrm{C}$ & 0 & -9 & & & $\begin{array}{l}6^{\circ} \text { min below ambient } \\
\text { temperature }\end{array}$ \\
\hline $\begin{array}{l}\text { SFC Aromatics } \\
\text { Mono- } \\
\text { Di- } \\
\text { Poly- }\end{array}$ & D5186 & $w t \%$ & $\begin{array}{l}0.1 \\
0.1 \\
0.1\end{array}$ & $\begin{array}{l}6.8 \\
1.1 \\
0.1 \\
\end{array}$ & & & \\
\hline $\begin{array}{l}\text { FIA } \\
\text { Aromatic } \\
\text { Olefins } \\
\text { Saturate }\end{array}$ & D1319 & vol\% & $\begin{array}{c}0.1 \\
0.1 \\
99.8\end{array}$ & $\begin{array}{r}7.8 \\
0.1 \\
92.1 \\
\end{array}$ & & & $35 \max$ \\
\hline Aromatics & - & mass $\%$ & & & & 18.1 & \\
\hline Gum Content & D381 & $\mathrm{mg} / \mathrm{lo0ml}$ & 0.2 & 0.5 & & & $10 \max$ \\
\hline Lubricity SLBOCLE & D6078 & grams & 1700 & 3900 & 4050 & & $3100 \mathrm{~min}$ \\
\hline Lubricity HFRR & D6079 & micron & $420 / 540 / 570$ & $590 / 570$ & 210 & & $380 \max$ \\
\hline $\begin{array}{l}\text { Carbon/Hydrogen } \\
\text { Carbon } \\
\text { Hydrogen } \\
\text { Nitrogen } \\
\text { Residual } \\
\text { Oxygen (by diff) }\end{array}$ & D5291 & mass $\%$ & $\begin{array}{c}84.91 \\
14.97 \\
0.67 \\
-1.09 \\
\text { Negligible } \\
\end{array}$ & $\begin{array}{c}85.54 \\
14.71 \\
0.35 \\
-0.595 \\
\text { Negligible } \\
\end{array}$ & & & \\
\hline $\begin{array}{l}\text { Heat of Combustion } \\
\text { Gross } \\
\text { Net }\end{array}$ & D240 & Btu/gal & $\begin{array}{l}132,600 \\
123,600 \\
\end{array}$ & & & $\begin{array}{l}136,400 \\
127,900 \\
\end{array}$ & \\
\hline
\end{tabular}

Net

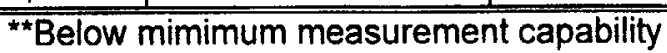


Table 2: Exhaust emissions from hot-start FTP engine tests in $\mathrm{g} / \mathrm{bhp}$-hr.

\begin{tabular}{|c|c|c|c|c|c|}
\hline \multicolumn{6}{|c|}{ Conventional No. 2 Diesel } \\
\hline Test \# & HC & CO & $\mathrm{NO}_{\mathrm{x}}$ & PM & $\mathrm{CO}_{2}$ \\
\hline 6199803 & 0.316 & 1.573 & 5.475 & 0.119 & 647.52 \\
\hline 6199804 & 0.352 & 1.578 & 5.367 & 0.121 & 641.86 \\
\hline 6199805 & 0.370 & 1.602 & 5.277 & 0.121 & 641.85 \\
\hline Average & 0.346 & 1.584 & 5.373 & 0.120 & 643.75 \\
\hline \multicolumn{6}{|c|}{ California No. 2 Diesel } \\
\hline Test \# & HC & $\mathrm{CO}$ & $\mathrm{NO}_{\mathrm{x}}$ & PM & $\mathrm{CO}_{2}$ \\
\hline 61998012 & 0.299 & 1.111 & 4.915 & 0.102 & 618.57 \\
\hline 61998013 & 0.293 & 1.136 & 5.049 & 0.106 & 615.06 \\
\hline 61998014 & 0.229 & 1.025 & 4.716 & 0.119 & 613.92 \\
\hline Average & 0.274 & 1.091 & 4.893 & 0.109 & 615.85 \\
\hline \multicolumn{6}{|c|}{ Fischer-Tropsch Diesel } \\
\hline Test \# & $\mathrm{HC}$ & $\mathrm{CO}$ & $\mathrm{NO}_{x}$ & PM & $\mathrm{CO}_{2}$ \\
\hline 6199807 & 0.211 & 0.991 & 4.722 & 0.108 & 610.88 \\
\hline 6199808 & 0.209 & 0.954 & 4.653 & 0.102 & 612.97 \\
\hline 6199809 & 0.174 & 0.959 & 4.445 & 0.101 & 610.62 \\
\hline Average & 0.198 & 0.968 & 4.607 & 0.104 & 611.49 \\
\hline
\end{tabular}

\section{VEHICLE TESTING}

TEST VEHICLES -The trucks used in this study were model year 1992 to 1994 White-GMC WG64T class 8 tractors $(80,000 \mathrm{lb}$ gross vehicle weight). The trucks were repowered with 1996 to 1997 Caterpillar 3176B diesel engines. Power System Associates (PSA) onverted four of the seven trucks in the study for dualruel compressed natural gas/diesel operation. The dualfuel engines are fully warranted by Caterpillar. One of the dual-fuel trucks is shown in Figure 3.

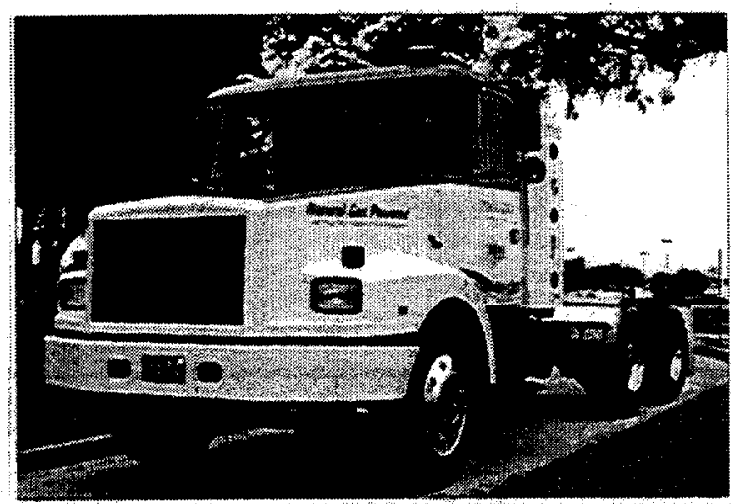

Figure 3: Pima Gro Inc. Dual-Fuel Compressed Natural Gas (CNG)/Diesel Truck

The Caterpillar $3176 \mathrm{~B}$ is an in-line, six cylinder, 10.3 liter electronically controlled engine. Both the diesel and dual-fuel engines tested in this program were rated at $260 \mathrm{~kW}$ (350 horsepower). The dual-fuel engines inject natural gas into the charge air in the intake manifold and Jnite the natural gas with a small charge of diesel fuel injected directly into the cylinder. By incorporating gas injectors into the intake manifold, the gas quantity is controlled for each cylinder, every cycle. Details of the design of the Caterpillar dual-fuel engines are presented in references [16-18].

CHASSIS EMISSIONS TESTING - West Virginia University (WVU) measured emissions for this study using one of its transportable emissions laboratories. The transportable laboratory consists of a heavy-duty chassis dynamometer and an emissions measurement facility. Design details of the laboratory and previous emissions measurements using the laboratory have been presented in several previous reports [19-27]

Chassis Dynamometer - The dynamometer equipment is mounted on a fifth wheel trailer for portability. Upon arriving at the test site, the wheels of the trailer are removed and the trailer is lowered to the ground. The test vehicle is driven onto two sets of free running rollers mounted in the trailer bed. Power is transferred from the test vehicle to the dynamometer through hub adapters that are bolted to the drive wheels. The inertia weight of the truck (set to $19,000 \mathrm{~kg}$ for this study) is simulated by a set of flywheels. The road load is applied to the test vehicle using air-cooled eddy current power absorbers. Figure 4 shows one of the test trucks mounted on the dynamometer.

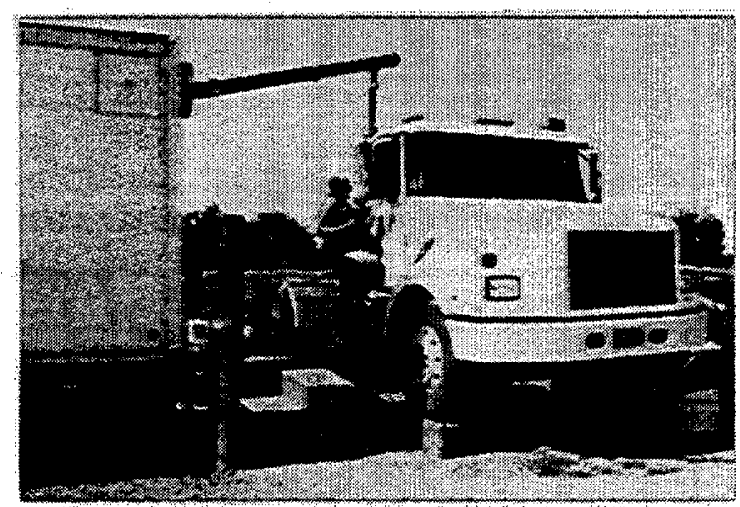

Figure 4: A diesel truck on the WWU transportable chassis dynamometer

Emissions Measurements - The emissions measurement system uses a $45.7 \mathrm{~cm}$ (18 in.) diameter, $6.1 \mathrm{~m}$ (20 ft.) long exhaust dilution tunnel mounted atop the box trailer that houses the emissions measuring equipment. Two fans and critical flow venturis control the flow rate in the dilution tunnel.

Carbon monoxide $(\mathrm{CO})$, carbon dioxide $\left(\mathrm{CO}_{2}\right)$, oxides of nitrogen $\left(\mathrm{NO}_{\mathrm{x}}\right)$, and total hydrocarbons (THC) are measured continuously throughout the test. Particulate matter (PM) is captured on a filter and weighed. Bag samples are collected and analyzed for background correction. When the vehicle being tested runs on natural gas, bags of diluted exhaust are collected and shipped to $W \cup U$ for methane analysis with a gas chromatograph.

Test Method - The trucks were tested using the WVU 5 -mile route. This test method is similar to the WWU 
5 -peak cycle reported earlier $[28,29]$. During the test, the truck is driven through five acceleration, cruise, and deceleration peaks. Each of the five cruise sections is at a different speed, from $32.2 \mathrm{~km} / \mathrm{hr}(20 \mathrm{mph})$ to 64.4 $\mathrm{km} / \mathrm{hr}(40 \mathrm{mph})$. Unlike the 5-peak cycle, which controls the rate of acceleration - thereby favoring trucks with high power-to-weight ratios - the 5-mile route allows the trucks to accelerate freely and adjusts the cruise time to keep the total distance covered constant. This allows the trucks to be driven in a manner that more closely represents on-road driving. More information on the 5 -mile route can be found in reference [30]. Figure 5 shows the actual speed-time trace of a vehicle following the 5-mile route running on conventional and F-T diesel. As shown in the figure, the free acceleration rate of the truck was the same on California and F-T diesel fuel. Drivers could not detect a performance difference between trucks operating on F-T diesel and California diesel.
Tests Performed -The emissions tests performed are outlined in Table 3.

Table 3: Emissions Tests Performed

\begin{tabular}{|l|l|c|}
\hline \multicolumn{1}{|c|}{ Engine } & \multicolumn{1}{|c|}{ Fuel } & $\begin{array}{c}\text { Number of } \\
\text { Tests }\end{array}$ \\
\hline $\begin{array}{l}\text { Cat 3176B } \\
\text { Diesel Engine }\end{array}$ & California Diesel & 3 \\
\cline { 2 - 3 } & 100\% F-T Diesel & 3 \\
\cline { 2 - 3 } & $50 \%$ F-T Diesel & 3 \\
\hline $\begin{array}{l}\text { Cat 3176B } \\
\text { Dual-Fuel Engine in } \\
\text { Diesel-Only Mode }\end{array}$ & California Diesel & 4 \\
\cline { 2 - 3 } & 100\% F-T Diesel & 2 \\
\hline $\begin{array}{l}\text { Cat 3176B } \\
\text { Dual-Fuel Engine in } \\
\text { Dual-Fuel Mode with } \\
\text { Natural Gas }\end{array}$ & CA Diesel Pilot & 4 \\
\cline { 2 - 3 } & F-T Diesel Pilot & 3 \\
\hline
\end{tabular}

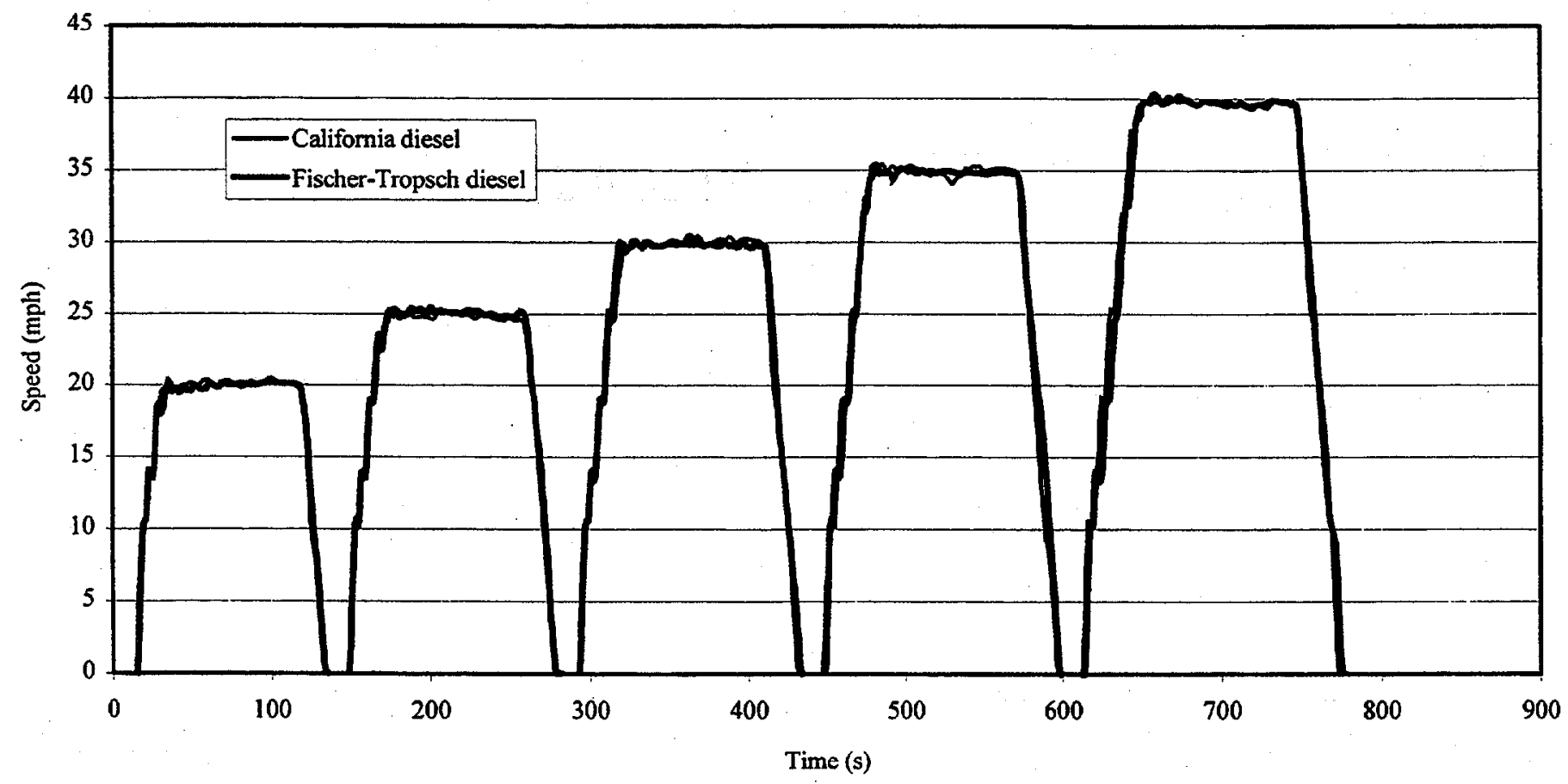

Figure 5: Speed-time trace of a test vehicle following the 5-mile route 
Table 4: Average emissions (in grams per mile) and fuel mileage from tractors tested on California specification diesel, Fischer-Tropsch diesel (F-T), and a 50:50 blend of the two fuels.

\begin{tabular}{|c|c|c|c|c|c|c|c|c|c|}
\hline Engine & Fuel & $\begin{array}{c}\text { Truck } \\
\text { Number }\end{array}$ & $\mathrm{CO}$ & $\mathrm{CO}_{2}$ & $\mathrm{NO}_{x}$ & $\mathrm{HC}$ & PM & MPG* & Btu/mile \\
\hline \multirow{9}{*}{ Diesel Engine } & California Diesel & 2011 & 2.77 & $\overline{1426}$ & $\overline{14.6}$ & 0.66 & 0.37 & 6.98 & 18300 \\
\hline & California Diesel & 2017 & 4.79 & 1784 & 13.3 & 0.69 & 0.61 & 5.58 & 22920 \\
\hline & California Diesel & 2016 & 4.26 & 1755 & 12.8 & 0.89 & 0.59 & 5.67 & 22541 \\
\hline & $50 \%$ F-T Diesel & 2011 & 2.53 & 1485 & 11.3 & 0.51 & 0.37 & 6.39 & 19681 \\
\hline & $50 \%$ F-T Diesel & 2017 & 4.33 & 1626 & 13.2 & $\overline{0.43}$ & 0.41 & 5.83 & 21569 \\
\hline & $50 \%$ F-T Diesel & 2016 & 3.74 & 1717 & 11.8 & 0.72 & 0.59 & 5.52 & 22774 \\
\hline & $100 \%$ F-T Diesel & 2011 & 2.55 & 1393 & 11.3 & 0.41 & 0.35 & 6.62 & 18701 \\
\hline & $100 \%$ F-T Diesel & $2017^{\star \star *}$ & 5.37 & 1453 & 19.5 & 0.33 & 0.30 & 6.32 & 19562 \\
\hline & $100 \%$ F-T Diesel & 2016 & 3.21 & 1634 & 11.2 & 0.50 & 0.48 & 5.63 & 21947 \\
\hline \multirow{6}{*}{$\begin{array}{l}\text { Dual-Fuel Engines } \\
\text { in Diesel-Only } \\
\text { Mode }\end{array}$} & California Diesel & 2019 & 3.97 & 1716 & 12.0 & 0.61 & 0.47 & 5.80 & 22025 \\
\hline & California Diesel & 2012 & 4.96 & 1863 & 14.0 & 0.52 & 0.50 & 5.34 & 23926 \\
\hline & California Diesel & 2020 & 3.85 & 1755 & 11.9 & 0.72 & 0.48 & 5.67 & 22526 \\
\hline & California Diesel & 2021 & 5.13 & 1816 & 11.1 & 0.76 & 0.62 & 5.48 & 23323 \\
\hline & $100 \%$ F-T Diesel & 2019 & 3.45 & 1645 & 10.7 & 0.36 & 0.33 & 5.59 & 22083 \\
\hline & $100 \%$ F-T Diesel & 2012 & 3.87 & 1709 & 13.7 & 0.33 & 0.30 & 5.38 & 22949 \\
\hline
\end{tabular}

* Miles per liquid gallon (not corrected for energy content)

** The driver during this test reported that truck 2017 began to behave erratically during the test on F-T diesel. The behavior was not attributed to the fuel. The truck displayed a "check engine" light shortly after being returned to the fleet. Data from this truck were not included in the averages shown in Figures 6 and 7.

Table 5: Comparison of emissions (in grams per mile) and fuel economy from dualfuel tractors tested using CNG with 100\% Fischer-Tropsch diesel or California specification diesel as pilot fuels.

\begin{tabular}{|l|c|c|c|c|c|c|c|c|}
\hline \multicolumn{1}{|c|}{ Pilot Fuel } & $\begin{array}{c}\text { Truck } \\
\text { Number }\end{array}$ & $\mathrm{CO}$ & $\mathrm{CO}_{2}$ & $\mathrm{NO}_{x}$ & $\begin{array}{c}\text { Total } \\
\mathrm{HC}\end{array}$ & $\mathrm{PM}$ & MPEG $^{*}$ & Btu/mile \\
\hline California Diesel & 2019 & 22.0 & 1444 & 8.17 & 61.8 & 0.43 & 5.98 & 21388 \\
\hline California Diesel & 2012 & 21.3 & 1494 & 10.2 & 60.2 & 0.37 & 5.82 & 21958 \\
\hline California Diesel & 2020 & 18.3 & 1453 & 10.8 & 47.3 & 0.43 & 6.13 & 20854 \\
\hline California Diesel & 2021 & 17.5 & 1533 & 15.7 & 45.1 & 0.56 & 5.87 & 21769 \\
\hline $100 \%$ F-T Diesel & 2012 & 21.7 & 1528 & 7.59 & 72.6 & 0.35 & 5.15 & 23976 \\
\hline $100 \%$ F-T Diesel & 2020 & 17.8 & 1471 & 7.36 & 80.2 & 0.42 & 5.27 & 23452 \\
\hline $100 \%$ F-T Diesel & 2021 & 16.3 & 1478 & 12.4 & 62.7 & 0.56 & 4.31 & 28649 \\
\hline
\end{tabular}

* Miles per Equivalent Gallon - Miles per diesel equivalent gallon containing 127,900 Btu for the California diesel and 123,600 for the Fischer-Tropsch diesel. 


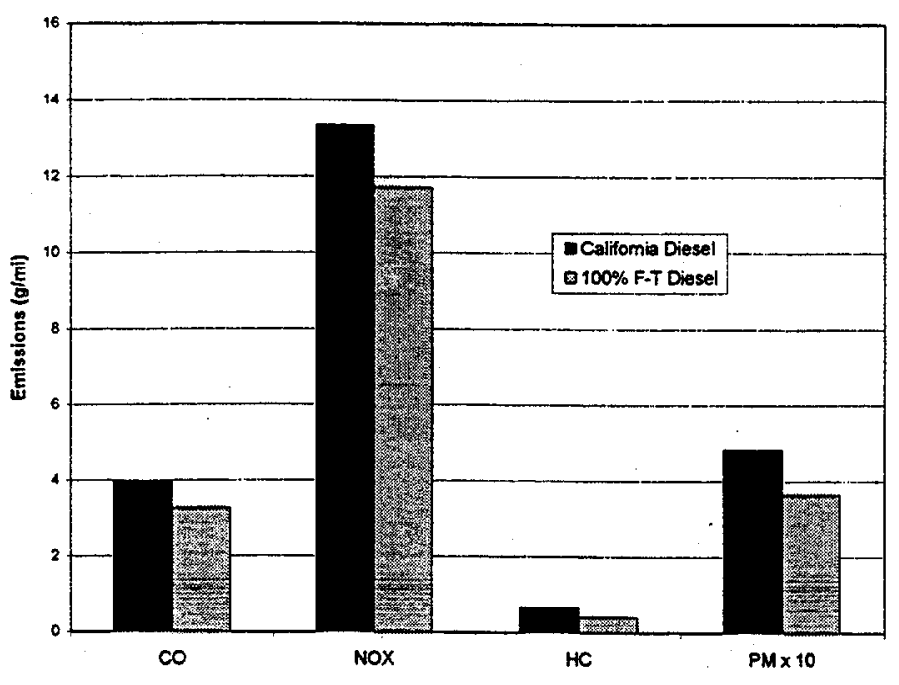

Figure 6: Average emissions from four trucks (2011, 2016,2012 , and 2019) operating on California diesel and $100 \%$ Fischer-Tropsch diesel.

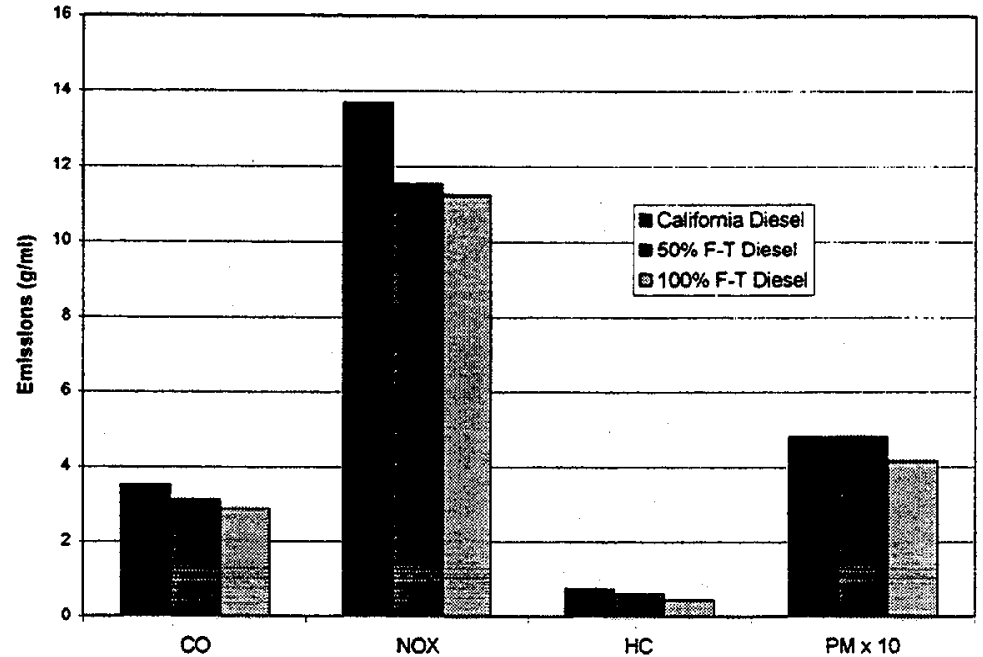

Figure 7: Average emissions from two diesel trucks (2011 and 2016) operating on California diesel, a 50\% FischerTropsch diesel blend and 100\% Fischer-Tropsch diesel.

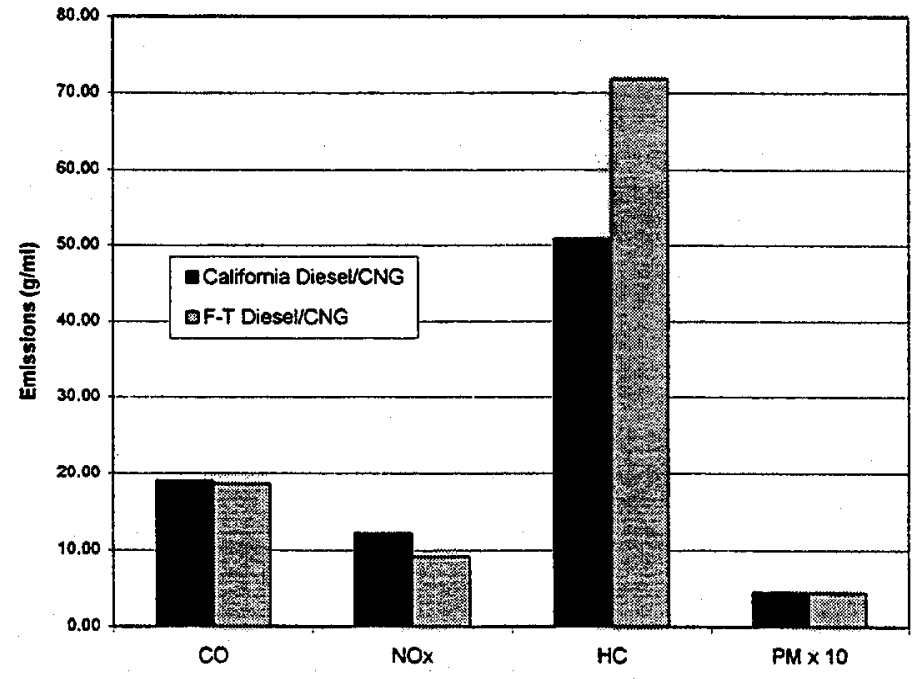

Figure 8: Average emissions from three dual-fuel trucks (2012, 2020, and 2021) operating on CNG with a California diesel and $100 \%$ Fischer-Tropsch diesel pilot charge.

\section{RESULTS}

The average emissions results are summarized in Tables 4 and 5 . At least three measurements were taken and averaged for each result presented in the tables.

Five trucks were tested on California diesel and $100 \%$ F-T diesel. The average results for four of these vehicles are illustrated in Figure 6. (The results for truck 2017 were not included in the average due to erratic behavior of the truck during testing.) Use of F-T diesel in place of California diesel in these trucks led to lower levels of all four emissions measured. $\mathrm{NO}_{x}$ was reduced by an average of $12 \%$, PM was reduced by an average of
$24 \%$, CO was reduced by an average of $18 \%$, and THC emissions were reduced by an average of $40 \%$.

These four trucks had essentially the same average fuel consumption on an equal energy basis when they were run on F-T diesel and California diesel. The truck-totruck variation in fuel consuption on California diesel (about 19\%) was much greater than the difference in fuel consumption for any given truck on California and F-T diesel (about $4 \%$ maximum). The lower heating value of the F-T diesel $(123,600 \mathrm{Btu} / \mathrm{gal})$ is about $3 \%$ less tha the California diesel $(127,900 \mathrm{Btu} / \mathrm{gal})$; therefore, the range of a truck on F-T diesel will be slightly less than on California diesel. 
Three diesel trucks were tested on California diesel, a $50 \%$ F-T and California diesel blend, and 100\% F-T diesel. Figure 7 shows the average results for two of these trucks (truck 2017 was not included in the average). The $50 \%$ blend reduced the $\mathrm{NO}_{x}$ emissions om the truck nearly as much as the neat F-T diesel, but PM emissions were not reduced.

Three dual-fuel trucks were tested with compressed natural gas as the primary fuel and either California diesel or F-T diesel as the pilot fuel. The average results of these tests are shown in Figure 8. The dual-fuel trucks emitted less oxides of nitrogen and higher carbon monoxide and total hydrocarbons than than the diesel trucks on both California diesel and F-T Diesel. Using the F-T diesel as the pilot fuel in place of California diesel lowered $\mathrm{NO}_{x}$ emissions by an average of $26 \%$ and increased THC emissions by an average of $41 \%$. CO and PM emissions were essentially unchanged.

\section{CONCLUSIONS}

- The Shell Fischer-Tropsch synthetic diesel fuel had properties conducive to low emissions, including a cetane number greater than 74 , sulfur content less than $5 \mathrm{ppm}$, and aromatic content of about $0.3 \%$ by weight.

- Fischer-Tropsch fuels and blends may require a lubricity additive to prevent undue fuel injection system wear based on rig test results. A commercially available lubricity additive was found to be effective for this study.

- Drivers could not detect a performance difference between trucks operating on F-T diesel and Califomia diesel.

- Use of Fischer-Tropsch diesel in place of California diesel in the test trucks led to lower levels of all four regulated emissions measured. Oxides of nitrogen were reduced by an average of $12 \%$, particulate matter was reduced by an average of $24 \%$, carbon monoxide was reduced by an average of $18 \%$, and total hydrocarbon emissions were reduced by an average of $40 \%$ for diesel-powered test trucks. Greater emissions benefits would be realized when subsituting Fischer-Tropsch diesel for 49-state No. 2 diesel.

- Vehicle performance and emissions results were promising enough to justify a more thorough fleet evaluation in revenue service with Fischer-Tropsch diesel.

\section{ACKNOWLEDGMENTS}

The authors would like to acknowledge the support and lard work of all of those involved in the dual-fuel truck project, the truck evaluation project, the emissions measurement effort, and the procurement and analysis of Fischer-Tropsch fuel: Mike Frailey, NREL; Cindy
Sullivan, South Coast Air Quality Management District ; Kevin Chandler, Battelle; Abang Abdul Rahim,Sheli; Leonard Gursky, Exxon; Paul Lacey, Southwest Research Institute; Ed Hodges, the County Sanitation District of Orange County; Gary Bruggeman, Pima Gro Systems, Inc.; Bob Shepherd, Power Systems Associates; Hal Wondolleck, Johnson Power Systems, and the West Virginia University laboratory staff.

\section{REFERENCES}

1. Fischer, F. and Tropsch, $H_{\text {., }}$ "Verfahren zur Gewinnung mehrgliedriger Paraffinkohlenwasserstoffe aus Kohlenoxyden und Wasserstoff auf katalytischem Wege, " DRP 484337 (German patent), 1926.

2. "The Slurry Phase Distillate Process, High Quality Diesel for a Cleaner World," Sasol Brochure, Sasol Synfuels International.

3. van Wechem, H.M.H. and Senden, M.M.G., "Conversion of natural gas to transportation fuels via the Shell Middle Distillate Synthesis Process," Natural Gas Conversion Symposium, Sydney, 1993.

4. Eilers, J. Posthuma, S.A. and Sie, S.T., "The Shell Middle Distillate Synthesis Process (SMDS)," Catalysis Letters, 7, 1990.

5. "Indirect Coal Liquefaction," at DOE Fossil Energy web site http://wuw.fe.doe.gov/coal_power.

6. Basta, N., "Gas-to-Liquid Synfuel Technology Steps Closer to Commercialization," at Hydrocarbon Online web site http://news.hydrocarbononline.com/featurearticles, 1997.

7. Gray, D. and Tomlinson, G., "Gas-to-Liquids: The Opportunities, Technologies and Issues,"

Proceedings on Gas-to-Liquids Processing-Bringing Clean Fuels to Market, Intertech Conferences, 1998.

8. Schaberg, P., Myburgh, I.S., Botha, J.J., Roets, P.N., Viljoen, C.L., Dancuart, L.P. and Starr, M.E., "Diesel Exhaust Emissions Using Sasol Slurry Phase Distillate Fuels," SAE Paper 972898, 1997.

9. Leet, J., "Potential Application of Fischer-Tropsch Fuels," Proceedings on Gas-to-Liquids ProcessingBringing Clean Fuels to Market, Intertech Conferences, 1998.

10. Peckham, J., "Reformulated Diesel Tests," Hart's Diesel Fuel News, Vol. 2, No. 10, May 21, 1998.

11. Martin, B., Aakko, P., Beckman, D., Giacomo, N.D., and Giavazzi, $F$., "Influence of Future Fuel Formulations on Diesel Engine Emissions-A Joint European Study," SAE Paper 972966, 1997.

12. Chandler, K., Norton, P. and Clark, N., "Alternative Fuel Truck Evaluation Project- Design and Preliminary Results," SAE Paper 981392, 1998.

13. Southwest Research Institute, Final Letter Report to NREL on Shell Fischer-Tropsch Fuels Tests, June 1998.

14. Analysts, Inc., Final Letter Report to WWU on California No. 2 Diesel Fuel Tests, July 1998.

15. Caterpillar Specifications for Distillate Fuel, Maintenance Section Fuel Specifications

16. Beck, N. J., Johnson, W. P., George, A. F., Petersen, P. W., van der Lee, B., and Klopp, G., 
'Electronic Fuel Injection for Dual Fuel Diesel Methane," SAE Paper 891652, 1992.

17. Gebert, K., Beck, N.J., Barkhimer, R.L., Wong, H.C., and Wells, A.D., "Development of Pilot Fuel Injection System for CNG Engines," SAE Paper 961100 , 1996.

18. Beck, N. J., Barkhimer, R. L., Johnson, W. P., Wong, H. C., and Gebert, K., "Evolution of Heavy Duty Natural Gas Engines - Stoichiometric, Carbureted and Spark Ignited to Lean Burn, Fuel Injected and Micro-Pilot," SAE Paper 972665, 1997.

19. Bata, R., Clark, N., Gautam, M., Howell, A., Long, T., Loth, J., Lyons, D., Palmer, M., Rapp, B., Smith, J., and Wang, W., "The First Transportable Heavy Duty Vehicle Emissions Testing Laboratory," SAE Paper 912668, 1991.

20. Bata, R., Clark, N., Lyons, D., Long, T., Howell, A., Loth, J., Palmer, M., Rapp, B., and Wang, W., "A Transportable Heavy Duty Vehicle Emissions Testing Laboratory: A New Dimension in Vehicle Testing," ASME Paper 92-ICE-21, 1992.

21. Clark. N. N., Gautam, M., Bata, R-M., and Lyons, D. W., "Design and Operation of a New

Transportable Laboratory for Emissions Testing of Heavy Duty Trucks and Buses," International Joumal of Vehicle Design: Heavy Vehicle Systems, Vol. 2, Nos. 3/4, pp. 285-299. 1995.

22. Clark. N. N., Lyons, D. W.. Wang, W., Rapp, B. L. Gautam, M., Wang, W., Norton, P., White, C., and Chandler, K., "Emissions from Trucks and Buses Powered by Cummins L-10 Natural Gas Engines," SAE Paper 981393, 1998.

23. Clark, N. N., Gautam M., Lyons, D. W., Bata, R. M., Wang, W., Norton, P., and Chandler, K. "Natural Gas and Diesel Transit Bus Emissions: Review and Recent Data," SAE Paper 973203, 1997.

24. Chandler, K., Malcosky, N., Motta, R., Norton, P., Kelly, K., Schumacher, L. and Lyons, D. W., "Alternative Fuel Transit Bus Evaluation Program Results," SAE Paper 961082, 1996.

25. Clark. N. N., Gadapati, C. J., Kelly, K., White, C. L., Lyons, D. W. Wang, W., Gautam, M. and Bata, R.; "Comparative Emissions from Natural Gas and Diesel Buses," SAE Paper 952746,1995.

26. Wang, W., Gautam, M., Sun, X., Bata, R-, Clark, N., Palmer, M. and Lyons, D. W., "Emissions
Comparisons of Twenty-Six Heavy Duty Vehicles Operated on Conventional and Alternative Fuels," SAE Paper 932952, 1993.

27. Bata, R, Lyons, D. W., Clark, N., Gautam, G. and Wang, W. , "Vehicle Performance and Exhaust Ga Emissions of In-use Methanol Fueled Transit Buses," Eleventh International Symposium on Alcohol Fuels, April 1996, Sun City, South Africa, Vol. 3, pp. 809-820,1996.

28. Clark, N. N., McKain, D. L., Messer, T. J., and Lyons, D., W., "Chassis Test Cycles for Assessing Emissions from Heavy Duty Trucks," SAE Paper 941946, 1994.

29. Clark, N. N., Messer, T. J.,, McKain, D. L., Wang, W. G., Bata, R. M., Gautam, M., and Lyons, D. W., "Use of the West Virginia University Truck Test Cycle to Evaluate Emissions from Class 8 Trucks," SAE Paper 951016, 1995.

30. Clark, N. N., Lyons, D. W., "Class 8 Truck Emissions Testing: Effects of Test Cycles and Data on Biodiesel Operation," American Society of Agricultural Engineers (ASAE) Paper 986082, 1998.

\section{DEFINITIONS, ACRONYMS, ABBREVIATIONS}

CNG - Compressed Natural Gas

CO - Carbon Monoxide

DDC - Detroit Diesel Corporation

DOE - U.S. Department of Energy

EPA - Environmental Protection Agency

EPACT - Energy Policy Act of 1992

F-T diesel - Fischer-Tropsch diesel

FTP - Federal Test Procedure

GTL - Gas-to-liquids

$\mathrm{HC}$ - Hydrocarbons

HFRR - High Frequency Reciprocating Rig

$\mathrm{NO}_{\mathrm{x}}$ - Oxides of Nitrogen

NREL - National Renewable Energy Laboratory

PM - Particulate Matter

ppm - parts per million

SLBOCLE - Scuffing Load Ball On Cylinder Lubricity Evaluator

SSPD - Sasol's Slurry Phase Distillate

THC - Total Hydrocarbons

WWU - West Virginia University 